\title{
PENERAPAN MODEL PEMBELAJARAN QUANTUM TEACHING UNTUK MENINGKATKAN AKTIVITAS DAN HASIL BELAJAR KONSTRUKSI BANGUNAN SISWA KELAS X TGB SMK NEGERI 2 MEDAN
}

\author{
Lisa Gusmira' ${ }^{1}$ Zulkifli Matondang ${ }^{2}$ \\ ${ }^{1}$ Alumni Program Studi Pendidikan Teknik Bangunan, Fakultas Teknik UNIMED \\ 2Dosen Pengajar Jurusan Pendidikan Teknik Bangunan, Fakultas Teknik UNIMED \\ (zulkiflimato@gmail.com)
}

\begin{abstract}
ABSTRAK
Penelitian ini bertujuan untuk meningkatkan aktivitas dan hasil belajar Konstruksi Bangunan dengan menerapkan model pembelajaran Quantum Teaching.Penelitian dikemas dalam dua siklus yang masing-masing terdiri dari dua kali pertemuan.Jenis penelitian ini adalah penelitian tindakan kelas yang terdiri dari tahapan perencanaan, tindakan, pengamatandan refleksi.Data penelitian diambil dari lembar observasidan tes hasil belajaryang sebelumnya telah di uji instrument.Penelitian ini dilakukan di SMK Negeri 2 Medan dengan jumlah sampel 30 siswa.Hasil penelitian menunjukkan bahwaaktivitas belajar siswapada siklus I yang mencapai kriteria Aktif ialah sebanyak 9 siswadan pada siklus II ialah sebanyak 26 siswa dengan nilai rata-rata akhir yaitu 80,33. Hasil belajarpada siklus I, persentase kelulusan yaitu $66.67 \%$ dengan nilai rata-rata 73,97 dan pada siklus II persentase kelulusan yaitu $86,67 \%$ dengan nilai rata-rata 81,75 . Jadi dapat disimpulkanbahwadengan dua siklus, model pembelajaran Quantum Teaching telah meningkatkan aktivitas dan hasil belajar siswa.
\end{abstract}

Kata Kunci : Aktivitas Siswa, Hasil Belajar, Model Pembelajaran, QuantumTeaching

\section{ABSTRACT}

This research aims to improve the activity and learning outcomes by implementing the Building Construction Quantum Teaching learning model. Research packed in two cycles each consisting of two meetings. This research is a classroom action research that consists of the stages of planning, action, observation and reflection. Data were taken from the observation sheet and test learning outcomes that have previously been tested instrument. This research was conducted in SMK Negeri 2 Medan with a sample of 30 students. The results showed that the learning activities of students in the first cycle, which reached Active criteria are as many as 9 students and the second cycle is that as many as 26 students with an average final value is 80.33. Learning outcomes in the first cycle, the passing rate is $66.67 \%$ with an average value of 73.97 and the second cycle passing rate is $86.67 \%$ with an average value of 81.75 . So it can be concluded that the two cycles, Quantum Teaching learning models have increased activity and student learning outcomes.

Keywords: Learning Model, Learning Outcomes, Student Activities, QuantumTeaching 


\section{Pendahuluan}

Dalam upaya peningkatan mutu pendidikan banyak hal yang harus diperhatikan, antara lain hasil belajar, proses belajar mengajar, metode pengajaran yang sesuai dengan materi ajar, fasilitas belajar, serta profesionalisme guru. Proses belajar mengajar merupakan unsur yang paling penting yang harus diperhatikan karena dengan pelaksanaan proses belajar mengajar yang baik tersebut tujuan pendidikan akan tercapai.SMK Negeri 2 Medan adalah salah satu sekolah menengah kejuruan yang memiliki beberapa program keahlian salah satunya Program Keahlian Teknik Bangunan yang terdiri dari 2 paket keahlian yaitu Teknik Gambar Bangunan (TGB) serta Konstruksi Batu dan Beton (KBB), Adapun salah satu mata pelajaran yang memiliki peranan penting dalam program keahlian teknik bangunan ialah mata pelajaran Konstruksi Bangunan.

Berdasarkan hasil observasi dan wawancara yang dilakukan peneliti dengan guru mata pelajaran Konstruksi Bangunan pada Februari 2015 di SMK Negeri 2 Medan, dikemukakan bahwa nilai mata pelajaran konstruksi bangunan belum mencapai kriteria ketuntasan minimum (KKM). Diketahui pada tahun pelajaran 2014/2015 dengan jumlah siswa 31 orang, yang memperoleh nilai $\leq 74$ kategori tidak kompeten sebanyak 32,25\%, nilai 75-79 kategori cukup kompeten sebanyak 22,58 $\%$, nilai 80-89 dengan kategori kompeten sebanyak 32,25\% dan nilai 90-100 kategori sangat kompeten sebanyak $12,90 \%$. Adapun untuk mata pelajaran Konstruksi Bangunan yaitu jika seorang siswa dikategorikan lulus/kompeten pada mata pelajaran konstruksi bangunan mampu mencapai nilai skor lebih besar atau sama dengan $(\geq)$ kriteria ketuntasan minimum yaitu $\geq 75$. Maka dengan itu dapat diketahui bahwa hasil belajar siswamasih perlu ditingkatkan lagi hingga terdapat sekurang-kurangnya $\geq 75 \%$ dari jumlah siswa yang berkompeten dengan nilai $\geq$ 75.

Diketahui bahwa hal ini disebabkan oleh beberapa faktor, salah satunya ialah kurangnya aktivitas belajar siswa.Kurangnya aktivitas belajar tersebut dikarenakan tidak adanya variasi dalam teknik pengajaran. Selama ini model pembelajaran yang diterapkan masih mengarah pada pembelajaran konvensional, dimana siswa cenderung diam sehingga siswa merasa bosan, tidak menikmati dan tidak termotivasi untuk mengikuti pembelajaran di kelas .Komponen yang menentukan dalam meningkatkan aktivitas belajar siswa adalah guru dan model pembelajaran yang digunakan.

Salah satu model pembelajaran yang dapat digunakan yaitu Quantum Teaching.Menurut DePorter. B, (2010) Quantum teachingberfokus pada hubungan dinamis dalam lingkungan kelas.Tahap yang sering dikenal sebagai kerangka rancangan quantum teaching yaitu TANDUR, dimana TANDUR merupakan singkatan dari tahapan-tahapannya yaitu Tumbuhkan, Alami, Namai, Demonstrasikan, Ulangi, dan Rayakan. Model pembelajaran ini diharapkan mampu meningkatkan aktivitas belajar dan hasil belajar siswa pada mata pelajaran konstruksi bangunan.

\section{Kajian Teori}

Aktivitas belajar merupakan segala kegiatan yang dilakukan dalam proses interaksi antara guru dan siswa atau siswa dengan siswa lain dalam rangka mencapai tujuan belajar. Aktivitas yang dimaksudkan disini penekanannya adalah pada siswa, sebab dengan adanya aktivitas dalam proses pembelajaran akan berdampak terciptanya situasi belajar aktif.Aktivitas belajar terdiri dari banyak sekali macamnya, oleh karena itu para ahli mengadakan klasifikasi. Paul B. Detrich dalam sardiman (2004:101) membuat suatu daftar yang berisi 117 macam kegiatan siswa yang digolongkan kedalam 8 kelompok, yaitu Visual Activities, Oral Activities, Learning Activities, Writting Activities, Drawing Activities, Motor Activities, Mental Activities, dan Emotional Activities. Menurut Sardiman (2004: 91) siswa dikatakan memiliki keaktifan apabila ditemukan ciri - ciri perilaku seperti: sering bertanya kepada guru atau siswa lain, mau mengerjakan tugas yang diberikan oleh guru, mampu menjawab pertanyaan, senang diberi tugas belajar, dan lain sebagainya.

Faktor-faktor yang mempengaruhi aktivitas belajar meliputi faktor internal, faktor eksternal dan pendekatan belajar siswa.Faktor internal meliputi; keadaan jasmani, kecerdasan, sikap minat bakat dan motivasi.Sedang faktor 


\section{Penerapan Model Pembelajaran Quantum Teaching Untuk Meningkatkan Aktivitas dan Hasil Belajar Konstruksi Bangunan Siswa Kelas X TGB SMK Negeri 2 Medan}

eksternal meliputi lingkungan sosial, yang berupa; keluarga, guru dan staf, masyarakat, teman dan juga lingkungan non sosial yang bisa berupa rumah, sekolah, peralatan dan alam. Aktivitas belajar dapat diukur dengan menggunakan lembar observasi, dimana didalam lembar observasi tersebut terdapat komponen - komponen dari aktivitas belajar seperti mengajukan pertanyaan, memberikan jawaban, memberikan pendapat, membuat kesimpulan, dan berdiskusi kelompok.

Belajar merupakan suatu proses interaksi antara siswa dengan lingkungannya yang dilakukan dengan sengaja pada berbagai jenjang pendidikan sehingga menimbulkan perubahan bagi siswa tersebut. Sardiman (2009), menyatakan bahwa hasil belajar adalah perubahan tingkah laku atau penampilan dengan serangkaian kegiatan membaca, mengamati, meniru, dan sebagainya. Maka hasil belajar merupakan perubahan tingkah laku pada diri siswa yang disebabkan oleh adanya proses belajar. Menurut Nana Sudjana (2009), hasil belajar pada dasarnya merupakan akibat dari suatu proses belajar, hal ini berarti optimalnya hasil belajar seseorang akan mengalami perubahan dalam tingkah lakunya. Jadi dapat disimpulkan bahwa hasil belajar merupakan perubahan dari dalam diri siswa yang dihasilkan dari suatu proses belajar yang tidak hanya berupa pengetahuan melainkan berupa penghayatan dalam diri pribadi dalam tiga ranah penting yaitu ranah kognitif, ranah afektif, dan ranah psikomotorik individu yang belajar.

Hasil belajar dipengaruhi oleh faktor internal dan faktor eksternal.Faktor internal merupakan faktor yang terdapat dalam diri siswa termasuk pula aktivitas belajar siswa. Sedangkan faktor eksternal adalah faktor yang mempengaruhi proses belajar termasuk didalamnya ialah kebersihan, fasilitas, kemampuan guru, serta model pembelajaran yang digunakan guru dalam pembelajaran.Hasil belajar konstruksi bangunan merupakan pencapaian keberhasilan yang didapatkan siswa dari proses pembelajaran dalam memenuhi kompetensi dalam tiga aspek penting berupa pengetahuan, sikap dan keterampilan, yang diukur menggunakan tes tertulis pada mata pelajaran konstruksi bangunan.

Model pembelajaran adalah suatu perencanaan atau suatu pola yang digunakan sebagai pedoman dalam merencanakan pembelajaran di kelas.Istarani (2011: 1) menyatakan bahwa model pembelajaran adalah seluruh rangkaian penyajian materi ajaryang meliputi segala aspek sebelum, sedang dan sesudah pembelajaran yang dilakukan guru serta segala fasilitas yang terkait yang digunakan secara langsung atau tidak langsung dalam proses belajar.Deporter B, dalam Ketut Trimawan (2014) menyatakan bahwa Quantum teaching adalah suatu model pembelajaran yang mampu menciptakan interaksi dan keaktifan siswa, sehingga kemampuan, bakat, dan potensi siswa dapat berkembang, yang pada akhirnya mampu meningkatkan prestasi belajar dengan menyingkirkan hambatan belajar melalui penggunaan cara dan alat yang tepat. Tahap yang sering dikenal sebagai kerangka rancangan quantum teaching yaitu TANDUR, dimana TANDUR merupakan singkatan dari tahapan-tahapannya yaitu Tumbuhkan, Alami, Namai, Demonstrasikan, Ulangi, dan Rayakan. Model pembelajaran ini diharapkan mampu meningkatkan aktivitas belajar dan hasil belajar siswa pada mata pelajaran konstruksi bangunan.

Model pembelajaran ini sebelumnya pernah diterapkan oleh hasil penelitian Pasaribu (2014) dalam penelitiannya diketahui bahwa nilai rata - rata hasil belajar MDGT siswa meningkat menjadi 81,78 dengan keterangan siswa Belum Tuntas (BT) tidak ada, Cukup (C) 7 orang, Baik (B) 20 orang, dan yang Sangat Baik (SB) 3 orang. Berdasarkan penelitian tersebut dapat disimpulkan bahwa dengan penerapan model pembelajaran Quantum Teaching, aktivitas dan hasil belajar siswa meningkat.Selain itu Purwadari (2009) melalui penelitiannya dalam menerapkan model pembelajaran quantum teaching terbukti dapat meningkatkan kemampuan menulis fiksi mahasiswa dari nilai rata-rata 58,35 menjadi 70,45 .

\section{Metodologi Penelitian}

Jenis penelitian ini merupakan penelitian tindakan kelas.Penelitian ini dilakukan untuk mengetahui apakah penerapan model pembelajaran dapat meningkatkan aktivitas dan hasil belajar siswa pada mata pelajaran Konstruksi Bangunan pada kompetensi dasar menerapkan dan mengelola spesifikasi dan 
karakteristik bahan adukan dan pasangan di kelas X Program Keahlian Teknik Gambar Bangunan SMK Negeri 2 Medan.

Penelitian ini dilaksanakan di SMK Negeri 2 Medan Jl. STM, Kampung Baru - Medan pada Kelas I Program Keahlian Teknik Gambar Bangunan.Penelitian ini dilaksanakan pada semester ganjil, yaitu bulan Juli 2015 sampai dengan selesai.Dalam penelitian ini yang menjadi subjek penelitian adalah siswa kelas $X$ TGB 1 Program Keahlian Teknik Gambar Bangunan di SMK Negeri 2 Medan Tahun Ajaran 2015/2016 dengan jumlah sebanyak 31 siswa.Penelitian ini dibantu oleh satu orang guru mata pelajaran konstruksi bangunan sebagai pelaku tindakan dan peneliti sebagai observer serta bermitra dengan pihak lain, seperti teman sejawat mahasiswa untuk membantu dalam melaksanakan penelitian tindakan kelas.

Adapun langkah-langkah yang akan dilakukan dalam proses penelitian tindakan ini adalahMasing-masing siklus terdiri dari empat tahap yaitu perencanaan (planning), pelaksanaan (acting), pengamatan (observing), dan refleksi (reflecting). Penelitian ini diawali dari melakukan observasi lingkungan sekolah, guru yang sedang mengajar dan siswa yang menjadi objek penelitian lalu melakukan diskusi dengan PKS I danbekerjasamadengan guru mata pelajaran Konstruksi Bangunan pada Kompetensi dasar menalar dan mengolah spesifikasi dan karakteristik bahan adukan dan pasangan untuk menganalisis kurikulum tentang penerapan model pembelajaran kuantum (Quantum Teaching) dalam belajar. Kemudian guru melakukan proses pembelajaran dengan menggunakan model pembelajaran Quantum Teachingdengan menjelaskan terlebih dahulu cara kerja model pembelajaran Kuantum ini kepada siswa, saat proses belajar mengajar berlangsung, peneliti mengamati siswa saat melakukan aktivitas belajar berupa mengajukan pertanyaan, memberikan jawaban, memberikan pendapat, membuat kesimpulan, dan berdiskusi kelompok.Setelahproses pembelajaran dengan menggunakan model pembelajaran Quantum Teachingselesai maka disetiap akhir siklus, siswa diberikan tes kognitif yang sebelumnya telah diujikan validitas, uji kesukaran, daya beda dan reabilitasnya kepada siswa kelas XITGB1.dengan tujuan untuk mengetahui apakah hasil belajar dan aktivitas siswa mengalami peningkatan.Kemudian peneliti melakukan refleksi dengan melihat hasil tes belajar siswa yang dijadikan sebagai dasar untuk melaksanakan siklus berikutnya.

Tes kognitif hasil belajar siswa adalah seperangkat tes kognitif dalam bentuk objektif tes dengan pilihan berganda sebanyak 42 soal dengan empat pilihan.Soal yang dijawab benar diberi skor 1 dan salah diberi skor 0 . Pada siklus pertama sebanyak 21 soal, dan pada siklus kedua 21 soal yang digunakan untuk memperoleh data hasil belajar pada kompetensi yang ditentukan dalam kisi-kisi instrument. Tes yang berbentuk pilihan berganda yang terdiri dari 4 (empat) pilihan dimana jawaban benar diberi skor 1 (satu) untuk jawaban salah diberi skor 0 (nol).Observasi adalah teknik atau cara mengumpulkan dengan mengadakan pengamatan terhadap kegiatan yang sedang berlangsung. Observasi digunakan untuk mengumpulkan data aktivitas belajar siswa dalam proses belajar mengajar dengan penerapan model pembelajaran Quantum Teaching.

\section{Hasil dan Pembahasan}

Sebelum digunakan sebagai alat pengumpul data, tes hasil belajar tersebut diujicobakan pada siswa di luar sampel yaitu siswa yang telah mempelajari pokok bahasan dalam instrumen penelitian, serta didiskusikan bersama para ahli statistik terlebih dahulu sehingga dapat diketahui validitas, reliabilitas, tingkat kesukaran, dan daya pembeda tes tersebut. Sedangkan instrumen nontes dalam penelitian ini berupa observasi, harus didiskusikan bersama para ahli sehingga diperoleh validitas isi intrumen nontes tersebut. Uji instrumen dilaksanakan dikelas XI Program Keahlian Teknik Gambar Bangunan SMK Negeri 2 Medan.

Pada siklus pertama penelitian dilaksanakan dua kali pertemuan, pertemuan pertama dilaksanakan pada hari Kamis, 13 Agustus 2015 dan pertemuan kedua dilaksanakan pada hari Kamis, 20 Agustus 2015. Pada siklus pertama dilakukan pembelajaran terhadap siswa kelas X Program Keahlian Teknik Gambar Bangunan SMK Negeri 2 Medan dengan menerapkan model pembelajaran Quantum teaching dan selama pembelajaran berlangsung peneliti mengamati aktivitas belajar siswa. Pada akhir siklus I, siswa diberikan soal tes yang terdiri dari 21 soal yang telah diujikan terlebih dahulu pada 


\section{Penerapan Model Pembelajaran Quantum Teaching Untuk Meningkatkan Aktivitas dan Hasil Belajar Konstruksi Bangunan Siswa Kelas X TGB SMK Negeri 2 Medan}

siswa kelas XI TGB SMK Negeri 2 Medan. Setelah itu, Peneliti melakukan analisis data dari nilai hasil belajar yang di peroleh pada siklus I, sebagai dasar peningkatan hasil belajar siswa pada siklus selanjutnya.

Setelah dilakukan proses pembelajaran selama dua pertemuan di siklus I dengan penerapan model pembelajaran Quantum Teaching hasilnya adalah dapat diketahui bahwa hasil belajar siswa berhasil meningkat namun presentase kelulusan siswa belum mencapai nilai indikator keberhasilan siswa yaitu minimal nilai 75 dengan ketercapaian klasikal sekurang-kurangnya $75 \%$ dari seluruh jumlah siswa tuntas belajar mengacu pada kriteria ketuntasan belajar minimum yang diterapkan SMK Negeri 2 Medan.Dari hasil pengamatan peneliti dan dibantu dengan guru menyimpulkan bahwa pelaksanaan belum sesuai dengan rencana. Hal ini disebabkan oleh sebagian siswa belum terbiasa dengan kondisi belajar yang mengarah pada model pembelajaran Quantum Teaching. Hal tersebut disebabkan karena selama ini guru hanya memberi pelajaran dengan metode ceramah lalu memberikan tugas untuk dikerjakan siswa.Siswa juga belum memahami langkahlangkah Quantum Teaching secara utuh dan menyeluruh. Hal ini dapat dilihat dari hasil penelitian pada siklus I rata-rata aktivitas belajar siswa hanya mencapai 52,33 pada pertemuan pertama dan hanya terdapat 4 orang siswa yang mampu mencapai nilai 75 sedangkan pertemuan kedua nilai rata-rata aktivitas siswa mencapai 63,33 dengan 9 orang siswa yang mampu mendapatkan nilai $\geq 75$. Dan dilihat dari data hasil belajar siswa pada siklus I, nilai rata-rata hasil belajar siswa adalah 73,97 dan 66,67\%(20orang siswa) yang mencapai nilai $\geq 75$.

Untuk memperbaiki kesalahan pada siklus pertama, maka pada siklus kedua peneliti bersama guru melakukan perencanaan ulang terhadap proses pembelajaran mengenai indikator yang belum tercapai yaitu untuk aktivitas indikator yang belum tercapai adalah sebagian siswa belum berani untuk mengajukan pertanyaan, memberi jawaban, dan memberikan pendapat. Guru juga akan memberikan motivasi kepada siswa dengan contoh-contoh praktis antara materi yang akan diajarkan dengan contoh nyata yang ada dalam kehidupan sehari-hari lalu dengan intensif memberi pengertian kepada siswa kondisi belajar dan membantu siswa yang belum memahami langkah-langkah pembelajaran dengan menggunakan model Quantum Teaching.

Pada siklus II penelitian dilaksanakan dua kali pertemuan, pertemuan ketiga dalam penelitian ini dilaksanakan pada hari Kamis, 27 Agustus 2015 dan pertemuan keempat dilaksanakan pada hari Kamis, 3 September 2015 dan dilakukan terhadap siswa kelas $X$ TGB 2 Program Keahlian Teknik Gambar Bangunan SMK Negeri 2 Medan dengan menerapkan model pembelajaran Quantum teaching dan selama pembelajaran berlangsung peneliti mengamati aktivitas belajar siswa . Pada akhir siklus II ini, siswa diberikan soal tes yang terdiri dari 21 soal yang telah diujikan terlebih dahulu pada siswa kelas XI TGB SMK Negeri 2 Medan. Setelah selesai maka peneliti melakukan analisis data yang diperoleh pada siklus kedua dan merekap semua data siklus II.

Berdasarkan kelima indikator observasi aktivitas sudah menunjukkan bahwa siswa sudah mulai terbiasa model pembelajaran Quantum Teaching. Setelah dilakukan pembelajaran dengan menggunakan model pembelajaran ini, siswa lebih leluasa mengemukakan pendapat serta mengajukan pertanyaan mengenai materi yang belum dipahaminya.Beberapa siswa juga dapat menyimpulkan materi secara rinci dengan menggunakan bahasa mereka sendiri dalam bentuk catatan.Siswa juga sangat antusias dalam berdiskusi kelompok.Aktivitas siswa dalam mengikuti proses pembelajaran sudah mencapai target pada siklus II. Hal ini dapat dilihat dari data hasil penelitian aktivitas siswa pada pertemuan ketiga nilai rata-rata aktivitas siswa adalah 73,17 dan terdapat 63,3\% (19 siswa) yang mencapai target yaitu mendapat nilai $\geq 75$ dan pada pertemuan keempat nilai rata-rata aktivitas siswa mengalami peningkatan yaitu 80,33 dengan capaian target $87 \%$ (26 siswa) yang mendapat nilai $\geq 75$. Dan diketahui bahwa hasil belajar siswa pada akhir siklus II meningkat dan mencapai target yaitu nilai rata-rata hasil belajar adalah 81,75 dan sebanyak $86,67 \%$ (26orang siswa) mencapai nilai $\geq 75$.

Dari hasil penelitian dan ketercapaian indikator pada Siklus II di atas, maka dapat disimpulkan bahwa Hasil ini dapat dikatakan telah memenuhi target karena rata-rata komulatif kelas sudah $\geq 75 \%$ mendapat nilai 
minimal 75,sehingga dapat dikatakan bahwa kelas mengalami peningkatan, makasiklus selanjutnya tidak perlu dilakukan lagi. Oleh karena itu, Penerapan Model Pembelajaran Quantum Teaching dapat Meningkatkan Aktivitas dan Hasil Belajar konstruksi bangunan Siswa Kelas X Program Keahlian Teknik Gambar Bangunan SMK Negeri 2 Medan.

\section{Kesimpulan dan Saran}

\subsection{Kesimpulan}

Berdasarkan hasil penelitian tindakan kelas (PTK) dapat disimpulkan Penerapan model pembelajaran Quantum Teaching dapat meningkatkan aktivitas belajar siswa mata pelajaran Konstruksi Bangunan pada Siswa Kelas X Program Keahlian Teknik Gambar Bangunan SMK Negeri 2 Medan. Hal ini dapat diketahui dengan nilai rata-rata hasil observasi aktivitas belajar siswa yang mengalami peningkatan, yaitu pada siklus I dengan nilai rata-rata komulatif kelas 63,33 dengan Persentase kelulusan yaitu $30 \%$ meningkat menjadi 80,33 dengan Persentase kelulusan 80,33\% pada siklus II.Dan penerapan model pembelajaran Quantum Teaching dapat meningkatkan hasil belajar konstruksi bangunan pada siswa Kelas $X$ Program Keahlian Teknik Gambar Bangunan SMK Negeri 2 Medan. Hal ini dapat diketahui dengan nilai rata-rata hasil belajar siswa mengalami peningkatan, yaitu pada siklus I nilai rata-rata komulatif kelas 73,97 dengan Persentase siswa tuntas belajar $66,7 \%$ menjadi 81,75 dengan persentase siswa tuntas belajar $86,7 \%$ pada siklus II.

\subsection{Saran}

Setelah melihat hasil penelitian, pembahasan dan kesimpulan maka peneliti memberikan saran sebagai berikut:

a. Bagi Kepala SMK Negeri 2 Medan

Karena kegiatan ini sangat bermanfaat khususnya bagi sekolah, maka diharapkan mendukung pelaksanaan secara berkesinambungan sebagai referensi yang dapat digunakan oleh guru mata pelajaran lain.

b. Bagi Guru

Dalam kegiatan belajar mengajar guru diharapkan menjadikan model pembelajaran Quantum Teaching sebagai suatu alternatif dalam mata pelajaran Konstruksi Bangunan untuk meningkatkan aktivitas dan hasil belajar siswa. Guru diharapkan mampu menjadi fasilitator yang terus-menerus membimbing siswa dalam membangun sendiri pengetahuan dalam menyelesaikan permasalahan materi pembelajaran.

c. Bagi Siswa

Model pembelajaran Quantum Teaching ini dirancang untuk mengatasi kesulitan belajar siswa secara individual. Oleh karena itu kegiatan pembelajarannya lebih banyak digunakan untuk pemecahan masalah. diharapkan siswa dapat menggali kemampuan individu yang dimiliki dan mengembangkan rasa kepercayaan diri. Dengan demikian siswa diharapkan memiliki keaktifan belajar yang tinggi di dalam menerima suatu materi pelajaran, hal ini akan berdampak positif bagi hasil belajar siswa itu sendiri.

\section{Daftar Pustaka}

Deporter, Bobby .2010.Quantum Teaching :Mempraktekkan Quantum Learning di Ruang-Ruang Kelas. Bandung: Kaifah.

Istarani, 2011.Pembelajaran Kooperatif.Yogyakata : Pustaka Belajar

Ketut Trimawan, I. 2014. Penerapan model quantum teaching untuk meningkatkan hasil belajar IPA.Jurnal mimbar PGSD (Online), vol. 2, no.1, http://isjd.pdii.lipi.go.id/admin/jurnal/6 10982101.pdf, diakses pada 25 oktober 2015.

Naim, Muhammad. 2009. Penerapan metode quantum teaching dengan teknik peta pikiran (mind mapping) dalam pembelajaran fisika. Jurnal ilmiah (online), vol $6, \quad$ no.1, http://isjd.pdii.lipi.go.id/admin/jurnal/6 10982100.pdf

,diakses pada 23 oktober 2015.

Pasaribu, Kristina Hariana.2014.Penerapan Strategi Pembelajaran Kuantum (Quantum Teaching) Untuk Meningkatkan Aktivitas $\mathcal{E}$ Hasil Belajar Menerapkan Dasar- Dasar Gambar Teknik (Mdgt) Siswa Kelas X Program Keahlian Gambar Bangunan Smk Negeri 1 Lubuk Pakam. Medan : Unimed 
Pudawari. 2009. Penggunaan model quantum Teaching dalam meningkatkan kemampuan menulis fiksi mahasiswa. Jurnal pendidikan (online), vol.10, no.1 (http://jurnal .pdii.lipi.go.id/admin/jurnal/1010095259. pdf, diakses pada 23 oktober 2015)

Sardiman, AM. 2009. Interaksi Belajar dan Mengajar . Jakarta: RajaGrafindo Persada.

Sudjana, N. 2009.Penilaian Hasil Belajar Proses belajar mengajar .cetakan ke-14. Bandung : Remaja Rosdakarya 